\title{
The Rights of the Adolescent: The Mature Minor
}

Roxanne Mykitiuk

Osgoode Hall Law School of York University, rmykitiuk@osgoode.yorku.ca

Victoria J. Davis

Source Publication:

Journal of Obstetrics and Gynaecology Canada. Volume 23, Number 4 (2001), p. 343-345.

Follow this and additional works at: https://digitalcommons.osgoode.yorku.ca/scholarly_works

Part of the Health Law and Policy Commons, and the Sexuality and the Law Commons c) (1) $(9)$

This work is licensed under a Creative Commons Attribution-Noncommercial-No Derivative Works 4.0 License.

\section{Recommended Citation}

Mykitiuk, Roxanne, and Victoria J. Davis. "The Rights of the Adolescent: The Mature Minor." Journal of Obstetrics and Gynaecology Canada 23.4 (2001): 343-345.

This Article is brought to you for free and open access by the Faculty Scholarship at Osgoode Digital Commons. It has been accepted for inclusion in Articles \& Book Chapters by an authorized administrator of Osgoode Digital Commons. 


\section{The Rights of the Adolescent: The Mature Minor}

Victoria J. Davis, MD'

Roxanne Mykitiuk, BA, LLB, LLM²

1 Department of Obstetrics and

Gynecology

University of Toronto

The Hospital for Sick Children

Toronto ON

2 Osgoode Hall Law School

York University

Toronto ON
Abstract: Health care providers who treat adolescents may also be required to diagnose and treat the reproductive health conditions of minor patients and to facilitate health prevention measures, including contraception and testing for sexually transmitted diseases. Teens who do not want their parents to know about their sexual behaviour may consult a health care provider for reproductive or sexual health care services and treatment without parental knowledge or consent. This may present legal and ethical ditemmas for health care providers. Common law recognizes that adolescents under the legal age of majority who are sufficiently mature (the mature minor) may have the capacity to consent to health care services with the same independence as adults. Such capacity to consent needs to be determined on an individual basis. Where there is disagreement between a mature minor and her parent(s) about a medical procedure or treatment, the wishes of the adolescent should prevail. Under law, a married minor is usually treated as having attained majority sta- * tus; however, fertility services cannot ethically be denied if the unmarried adolescent is found capable and they are required medical services for that individual. Parents or legal guardians generally have the legal authority and responsibility to act as surrogate decision makers for adolescents found incapable of making their own health care decisions. Although confidentiality is essential, there are some exceptions to absolute confidentiality.

Résumé : Les fournisseurs de soins qui traitent les adolescents peuvent devoir examiner et traiter des patients mineurs pour des raisons de santé de la reproduction et les aider à prendre des mesures de prévention telles que la contraception et les tests de dépistage des MTS. Les adolescents qui ne veulent pas que leurs parents soient au courant de leur comportement sexuel peuvent consulter un fournisseur de soins pour recevoir des soins liés à leur santé sexuelle ou reproductive sans que leurs parents ne le sachent ou y consentent. Cetze situation peut présenter des dilemmes dordre légal ou éthique aux fournisseurs de soins. La common low reconnait que les adolescents qui n'ont pas atteint l'âge légal de la majorité, mais qui ont la maturité suffisante (« le mineur mûr ») peuvent être en mesure de consentir à des soins de santé avec la méme indépendance que les adultes. Une telle capacité de consentement doit être étabtie sự une base individuelle. Quand un mineur mûr et ses parents ne sont pas d'accord sur une procédure ou un traitement médical, la volonté de l'adolescent doit lemporter Selon la loi, un mineur marié est normalement traité comme ayant atteint l'âge de la maturité. Toutefois, les services liés à la fécondité ne peuvent pas, sur le plan éthique, être refúsés à un adolescent non marié si cet individu est jugé compétent et ils doivent lui être offerts. Les parents ou les tuteurs légaux ont l'autorité légale et la responsabilité d'agir en tant que fordés de pouvoir pour les adolescents qui ne sont pas jugés capables de prendre leurs propres décisions en matière de santé. Bien que la confidentialité soit essentielle, il existe des exceptions à la confidentialité absolue.

J Soc Obstet Gynaecol Can 2001:23(4):343-5

\section{INTRODUCTION}

Ignorance and misconceptions about adolescent sexuality prevail among adults and adolescents themselves. Thus, it is often the role and obligation of adolescent health care providers to dispel myths and to educate their parients about responsible and safer sexual behaviour to ensure sexual health. In addition to providing education, health care providers may also be required to diagnose and treat the reproductive health conditions of minor patients and to facilitare health prevention measures, including contraception and testing for sexually transmitted diseases. Teens who do not want their parents to know about 
their sexual behaviour may consult a health care provider for reproductive or sexual health care services and treatment without parental knowledge or consent. This may present legal and ethical dilemmas for health care providers who need to ensure a legally valid consent is given for any medical treatment or procedure and who may wonder whether an adolescent below the age of legal majority is able to provide this consent.

While for many purposes the age of majority or a staturorily defined age determines when an individual may legally participate in certain activities, there is no legally defined age for consent to medical treatment. Common law recognizes that adolescents under the legal age of majority who are sufficiently mature (the mature minor) may have the capacity to consent to health care services with the same independence as adults. ${ }^{1,2}$ To determine if an adolescent is capable of consent, the health care provider must decide if the adolescent is able to understand and appreciate the nature and consequences of the proposed medical procedure. ${ }^{3}$ Maturity is demonstrated when a minor has the intellectual capacity to understand critical information about prospective medical treatment, and the vision to make a responsible decision about her medical care. The key element, therefore, is the minor's competence and capacity to understand and decide, not chronological agè.

While adolescents may be able legally to consent to medical treatment and many have the decision-making capacities of an adult, ${ }^{4,5}$ determining whether a particular individual has the capacity to consent needs to be assessed on an individual basis. If the health care provider is unsure whether the minor has the requisite capacity, a colleague, bioethicist or psychiatrist could be called upon for a second opinion. Courts have recognized that the decisional capacity of a minor will vary with. the gravity of the decision and the degree of understanding and appreciation of the consequences of treatment and its alternatives. Thus the same individual may have the requisite capacity to consent to some medical services, but not others where the decision making process is more complex or the consequences more serious. Moreover, while one adolescent may be decisionally capable of consenting to a particular-medical service, another adolescent of the same age may not be. In the context of reproductive health, courts have held that a 15 -yearold had the capacity to consent to be fitted with an intrauterine device ${ }^{6}$ and that a pregnant 16 -year-old could give a valid consent to have a therapeutic abortion. ${ }^{7}$

Where there is disagreement between a mature minor and her parent about a medical procedure or treatment, the wishes of the adolescent should prevail, as the minor is capable of consenting to her own treatment. Therefore, the parent of a mature minor cannot veto the decision of a mature minor to have an abortion or to bring a pregnancy to term against the parent's will; choice in this matter belongs with the mature minor. ${ }^{8}$ As a general practice, however, the health care provider should discuss with the patient, and document, the importance of involving parents in health decisions, as well as the potential negative consequences of sexual activity and all of the options available (including abstinence).

Where the adolescent is capable of making a decision and understanding its consequences, that adolescent should have equivalent to adult access to all aspects of available reproductive health care. For example, while adolescents are less likely than adults to seek services for infertility, there are some cultures in which early marriage and childbirth are the norm. Consequently, physicians may refer a mature minor for fertility services when pregnancy is not forthcoming. Under law, a married minor is usually treated as having attained majority status; however, fertility services cannot ethically be denied if the unmarried adolescent is found capable and they are required medical services for that individual. Laws also tend to accept that an adolescent below the age of 18 attains majority starus on becoming a mother: this facilitates the younger mother in making health care decisions for her child. It would be contradictory for the mother to be able to make health care decisions for her child and not for herself.

In Ontario, statutory law provides that a person is capable, with respect to health treatment, if the person is both able to understand the information that is relevant to making a decision about the treatment and able to appreciate the reasonably foreseeable consequences of a decision or lack of a decision. ${ }^{8}$ The Health Care Consent Act makes no reference to an "age of consent," following in principle the "mature minor" rule that one's legal right to make health care decisions depends on one's decision-making ability rather than one's age. In some provinees, such as New Brunswick, British Columbia, and Quebec, legislation specifies an age at which an individual may give autonomous consent. ${ }^{9}$ These provisions extend the presumption of capacity to consent enjoyed by adults to minors. Even where legislation sets a minimum age for consent to procedures performed in hospitals, as is the case in Ontario, it has been argued that these provisions do not affect the general law of consent to medical treatment, but rather relate to the relationship between the hospital and health care provider and set a bureaucratic requirement to document evidence of consent. ${ }^{3}$ Therefore, if a mature minor who is under the minimum age specified in the statute consents to treatment in a hospital in the absence of parental consent (a therapeutic abortion for example), the consent will be valid vis-a-vis the treating physician and the hospital.

In the case of adolescents who are incapable of making their own health care decisions, parents or legal guardians generally have the legal authority and responsibility to act as surrogate decision-makers. The surrogate decision-maker is obliged to make trearment decisions in the best interest of the patient. If parental consent was given for medical treatment to an incapable minor who opposed and resisted the proposed treatment, it is possible to contest the parental decision to determine whether parental 
consent can be imposed in light of the minor's opposition to the treatment. In addition, health care providers who believe that a surrogates decisions are not in the best interest of the child can appeal to provincial child welfare authorities. ${ }^{10}$

The requirement that health care providers maintain patient confidentiality derives from the Hippocratic oath, and is a legal obligation. Unless assured of confidentiality, sexually active adolescents may forego counselling and contraception, thereby risking pregnancy, sexually transmitted diseases (STDs), and their sequelae. In order to maintain a therapeutic bond and ongoing care, the minor must trust the health care provider. Confidentialiry is essential. A mature minor is entitled to the same level of medical confidentiality as any other patient. There are, however, certain exceptions to absolute confidentiality. These are: the duty to warn third parties of imminent and serious danger (such as a positive HIV test); the disclosure of childbirth when necessary to protect the interests of the newborn child; disclosure when an adolescent requests health services because of sexual or other exploitation or abuise, against which parents may provide protection; 11,12 and the statutory dury to report any suspected cases of child abuse including sexual abuse, to a child protection agency.

An additional issue arises when the adolescent is not capable of making decisions about medical treatment, but does not want parents to know about the request for medical services.

Some argue that a health professional who does not disclose to parents may be acting in the best interest of the pritent. Others are of the view that a failure to disclose, especoly where the information is important to the welfare of the child; could be regarded as usurping the parent's role as substitute decisionmaker to determine what matters are relevant to the health care of the minor. Canadian courts have not determined whether a decisionally incapable minor can bind a health care provider to non-disclosure vis-a-vis parents. ${ }^{3}$

Health care providers need to be aware that it is a criminal offence for a person to involve a child under the age of 14 in any kind of sexual activity even if the child consents to the activity. The Criminal Code of Canada provides a defence where the victim is at least 12 years of age and under 14 and the accused person is at least 12 years of age and under 16, is less than two years older than the victim; and is neither in a position of trust or authority towards the victim nor is a person with whom the victim is in a dependent relationship. This information may be relevant to a health care worker providing contraceptive advice or sex education to a patient who is or is planning on engaging in sexual activity with a consenting partner, whose consent is vitiated by the operation of the Criminal Code.

In conclusion, health care providers need to respect, empower, and promote well-being in their patients, especially adolescents in the area of reproductive health care. The promotion of well-being includes education in all aspects of sexuality, so that negative sequelae can be reduced or avoided altogether, thus ensuring the right to reproductive health. A failure to discuss sexuality and sexual health means that adolescents often do not acquire the information and skills they need to prevent unintended pregnancy and sexually transmitted disease, and the consequent psychological impacts of these conditions. In addition to their direct involvement with adolescent patients, health care workers can also work with their local provincial governments to support and adopt policies and programs that respect; protect, and guarantee reproductive rights, including those of minors. This may require the creation of appropriate legislative, administrative, and budgetary measures to realize reproductive rights. However, if established, we can expect to see a decline in unintended pregnancy and STDs, and an increase in the number of youths who are empowered to deal more knowledgeably with their sexuality.

\section{REFERENCES}

1. Intem tional commission of Jurists. The Maastricht Guidelines on Violaton of Econothe Social and Cultural Rights.A compilation of essential doolineit Genova, 1997.

2. Rourovsky LF Rozoosky FA. The Canadian law of consent to treatment. Toronto Buturerworth, 1992:53-7.

3. Githoun MiMinors. In:Downie J, Cauffield T, Canadian Health Law and Policy Toronto Butterworth, 1999:185.

4. Weftion $L A$, Campell SB. The competency of children and addojescents to make informed treatment decisions. Child Der $1982 ; 53: 1589-98$.

5. Lewis CC. How adolescents approach decisions; changes over grades seven to twehe and policy implications. Child Dev $1981 ; 52: 538-44$.

6. Gillick w West Norfolk and Wisbech Area Heaith Authority, [1985] 3 All E.R. 402 (H.L)

7. C. (IS.) y.Wren [1987] 2 W.W.R. 669 (Alta. C.A.).

8. Cook R, Dickens BM. Recognizing adolescents' 'evolving capacities' to exercise choice in reproductive healthcare. Int / Gyn Obs 2000;70:13-21.

9. Etchells E, Sharpe G, Ellioe C, Singer PA. Bioethics for clinicians: 3: capacity. Can Med Assoc] 1996;155:657-61.

10. Harrison C, Kenry NP, Sidarous M, Rowell M. Bioethics for clinicians: 9. Involving children in medical decisions. Can Med Assoc J 1997;156:825-8

11. British Medical Association. Medical ethics today: its practice and philosophy. Br Med J 1993:87-8.

12. Kleinman 1, Baylis F, Rodgers S, Singer PA. Bioethics for clinicians: 8. confidentiality. Can Med Assoc ] 1997;156:521 -4. 